\title{
Economic and Technical Evaluation of Different Irrigation Systems for Date Palm Farming System in the GCC Countries: Case of Oman
}

\author{
Boubaker Dhehibi ${ }^{1}$, Mohamed Ben Salah², Aymen Frija ${ }^{3}$, Aden Aw-Hassan ${ }^{1}$, Hamdane El Ouhibi $^{4}$ \& \\ Youssef M. Al Raisi ${ }^{5}$ \\ ${ }^{1}$ Resilient Agricultural Livelihood Systems Program (RALSP), International Center for Agricultural Research in \\ the Dry Areas (ICARDA), Amman, Jordan \\ ${ }^{2}$ International Center for Agricultural Research in the Dry Areas (ICARDA), Directorate General of Agriculture \\ \& Livestock Research, Muscat, Oman \\ ${ }^{3}$ Resilient Agricultural Livelihood Systems Program (RALSP), International Center for Agricultural Research in \\ the Dry Areas (ICARDA), Tunis, Tunisia \\ ${ }^{4}$ Soil and Water Research Center, Directorate General of Agriculture \& Livestock Research, Muscat, Oman \\ ${ }^{5}$ Date Palm Research Center, Directorate General of Agriculture \& Livestock Research, Muscat, Oman \\ Correspondence: Boubaker Dhehibi, Resilient Agricultural Livelihood Systems Program (RALSP), International \\ Center for Agricultural Research in the Dry Areas (ICARDA), El-Rawaby Neighborhood- Behind Abdallah Abu \\ Ghosheh street, Yousef el sukkar street bldg. no 8, Amman, Jordan. E-mail: B.Dhehibi@cgiar.org
}

Received: February 27, 2018

Accepted: March 12, 2018

Online Published: July 16, 2018

doi:10.5539/enrr.v8n3p55

URL: https://doi.org/10.5539/enrr.v8n3p55

\begin{abstract}
In the frame of the ICARDA project "Development of sustainable date palm production systems in the GCC countries of the Arabian Peninsula", researchers succeeded to introduce one promising technology (subsurface drip irrigation - SDI) in the date palm farming system in the Gulf region, defined as the poorest in the word in terms of water resources. In the light of these challenges, the main objective of this study is to evaluate the effect of the irrigation water volumes on the date palm productivity and water use efficiency under several conventional and improved irrigations systems.

Three intervention levels on SDI have been used: at the rate of $60 \% 40 \%$ and $20 \%$ of water requirement. Results of this experimental study showed that SDI under the three intervention/options uses water more efficient in comparison to BI. Indeed, a considerable quantity of water for about $3545.554,5726.45$, and $7565.473 \mathrm{~m}^{3} /$ ha could be saved by using SDI at the rate of $20 \%, 40$ and $60 \%$ of water requirements, respectively. Thus, the WUE indicator is for about 2.0, 2.7 , and $4.7 \mathrm{~kg} / \mathrm{m}^{3}$, respectively. These figures are much higher when are compared to BI system where WUE is around $1.3 \mathrm{kgm}^{-3}$.

The economic evaluation suggests that under BI system, the total return, total variable costs, water costs and net profit were 20211.36, 5857.81, 1224.29, and 13129.25 $\$ \mathrm{ha}^{-1}$, respectively. From another hand, by using SDI at the rate of $60 \%$ of water requirements, we note a slight difference in net profit when using this irrigation system, which is about US\$12825.02/ha. Economic findings suggest that using SDI method versus BI method have additional cost but is economical at the long term as the SDI found to sustain the date palm farming system in this region where arid conditions acts as natural constraints for expansive agriculture.
\end{abstract}

Keywords: surface drip irrigation, economic valuation, technical valuation, date palm, Oman

\section{Introduction}

The present study is conducted within the framework of the "Development of Sustainable Date Palm Production Systems in Gulf Cooperation Council Countries" project funded by the Gulf Cooperation Council Secretariat (GCC). This research and development project aims to produce new knowledge and practices to improve date palm production systems in the Gulf region. The main activities of the project include improving the productivity of cultivars, managing natural resources (land and water) for optimal performance, optimizing the use of different inputs in the cropping process (fertilizers, pollinators, wastewater, etc.), and studying the genetic diversity of date palms. The transfer of technology and experience between partners is an integral part of the project. 
One promising technology introduced through the project is the subsurface drip irrigation. This technology has the advantage to potentially water saving, yield increases. It has the potential to be the most efficient irrigation method available today. Is also considered to be one of the most attractive and promising technologies for the Arab States of the Gulf countries, a region defined as the poorest in the word in terms of water resources where arid conditions in these countries act as a natural constraint for expansive agriculture.

The objective to introduce this technology was to provide water application strategies that maximize yield and minimize water loss for a range of irrigation system designs and applied for date palm farmers in the GCC countries Therefore, while developing improved technologies is important for farmers in the rural livelihoods for this region, new technologies can only affect livelihoods positively if they are profitable and by then adopted by farmers.

In the light of these challenges, the main objective of this study is to evaluate the effect of the irrigation water volumes on the date palm productivity and water use efficiency under several conventional and improved irrigations systems (surface, subsurface, bubbler, subsurface drip irrigation). It is mainly to investigate economically and technically the effectiveness of this introduced irrigation system in term of water use and requirement and yield productivity. Tis is mainly to compare this irrigation system (SDI) to several conventional irrigation systems used in the GCC countries in terms of water use efficiency and date palm yield productivity. The study is focusing on Oman, Saudi Arabia and Qatar.

\section{Date Palm Irrigation Systems in Oman}

According to Al Yahai and Khan (2015), irrigation water is traditionally delivered to date palm groves through open canals. Water sources are mainly underground aquifers in addition to wells or via the Falaj, - an ancient system of delivering water to farms in Oman. Other sources of water have also been explored, such as the utilization of treated wastewater (El Mardi et al., 1995, 1998), which is only used to little extend. The timing and frequency of irrigation is largely dependent on the allocated shares of water for each grove and is not based on empirical methods. Adoption of new methods of irrigation (such as bubbler irrigation, which is a localized, low pressure, solid permanent installation drip irrigation system), particularly in well-irrigated groves, is slowly gaining momentum as the installation is being subsidized by the government. Al-Yahyai and Al-Kharusi (2012b) reported also that chemical quality attributes of date palm (cv. Khalas) grown in northern Oman varied in response to decreased frequency of irrigation water applied during fruit development.

Nowadays, about $75 \%$ of date palm trees in the Sultanate is irrigated by the flood irrigation system that uses an abundant quantity of water. The remaining $25 \%$ is irrigated by bubbler irrigation systems. Moreover, the quantity of water required at the farm level is determined by the farmer's experience. The application of traditional irrigation system (flood irrigation) is putting a pressure on the existing water resources and, consequently led to the waste of large volumes of this valuable resource. Indeed, the adoption of modern irrigation techniques such as drip and subsurface drip irrigation is more than needed today for this very arid region. This is mainly to increase water use efficiency and productivity of the grown date palms.

Several previous studies indicated that subsurface drip irrigation is one of the promising technologies that contributes to improve water use efficiency and productivity. In addition, it is considered as the most effective way to provide water and nutrient directly to the plant and to increase crops productivity (Tiwaki et al., 1998; Thomson et al., 2002, 2003). This subsurface drip irrigation represents the recent improvement of irrigation as it significantly reduces losses of direct evapotranspiration, runoff, and deep percolation (Hanson \& May, 2007; Safi et al., 2007). It is within this framework that the project "Development of sustainable date palm production systems in the GCC countries of the Arabian Peninsula", funded by the GCC, implemented, in partnership, by ministries of agriculture, agricultural authorities, and agricultural research institutions and universities in the six GCC countries of the Arabian Peninsula (Kingdom of Bahrain, United Arab Emirates, State of Kuwait, State of Qatar, Sultanate of Oman, and Kingdom of Saudi Arabia) and the International Center for Agricultural Research in the Dry Areas (ICARDA). The major objectives of the project are to increase propagation efficiency and expedite production of offshoots in the quantities needed by growers at a reduced cost; improve date palm productivity per unit of water on supporting the widespread of this subsurface drip irrigation technology, and rationalize the use of the available resources so that production becomes sustainable.

Many studies suggest the use of subsurface drip irrigation as a water saving technology in arid areas, but it is necessary to study and examine the performance and the efficiency of this irrigation technology in comparison with other irrigation systems such as bubbler irrigation systems which is also being used in these areas. The main objective of this study is to examine the efficiency of subsurface drip irrigation system for young palm trees in the Sultanate of Oman in terms of both water use efficiency, yield and economic viability of this system in comparison 
to the existing bubbler irrigation system. Our results will help to identify the most efficient technique for water conservation (Technically and economically) as well as the most profitable.

\section{Material and Methods}

\subsection{Purpose of the Experimental Research Study in Oman}

The main objective of this study is to evaluate the effect of the irrigation water volumes on the date palm productivity and water use efficiency under the subsurface drip irrigation system. It is mainly to investigate economically and technically the effectiveness of this irrigation system in term of water use and requirement and yield productivity. Tis is mainly to compare the bubbler irrigation system (BI) and the subsurface irrigation system (SDI) in terms of water use efficiency and date palm yield productivity (Khalas variety). The experience was conducted in the Research Agricultural Station in Al Kamil and Al Wafi at the Sharqyiah Governorate - Sultanate of Oman.

\subsection{Location and Site Characteristics}

Site localization: The experiment was conducted at the experimental station at the Research Agricultural Station, Al Kamil and Al Wafi, Sharqiyah Governorate, Sultanate of Oman (22 $14^{\prime} 13.00$ N, $59^{\circ} 11^{\prime} 04.00$ E).

Site characteristics: The soil profile of the experimental site in the upper 0-30 $\mathrm{cm}$ soil was sandy loam texture composed of $72 \%$ sand, $11.11 \%$ silt and $16.23 \%$ clay. The average values of $\mathrm{PH}$ and EC were 7.6 and $1.12 \mathrm{Ds} \mathrm{m}^{-1}$, respectively.

Table 1. Physical and chemical properties of the filed at different soil layers

\begin{tabular}{|c|c|c|c|c|c|c|c|c|c|c|}
\hline \multirow[b]{2}{*}{$\begin{array}{l}\text { Soil Depth } \\
\text { (cm) }\end{array}$} & \multicolumn{5}{|c|}{ Particle size distribution (\%) } & \multirow[b]{2}{*}{ PH } & \multirow[b]{2}{*}{$\begin{array}{c}\text { Ca } \\
\text { Meq/l }\end{array}$} & \multirow[b]{2}{*}{$\begin{array}{c}\text { Mg } \\
\text { Meq/l }\end{array}$} & \multirow[b]{2}{*}{$\begin{array}{c}\mathrm{CaCo3} \\
\%\end{array}$} & \multirow[b]{2}{*}{$\begin{array}{c}\text { ECe } \\
\left(\mathrm{dS} \mathrm{m}^{-1}\right)\end{array}$} \\
\hline & $\begin{array}{c}\text { Gravel } \\
(\%) \\
\end{array}$ & $\begin{array}{c}\text { C.Sand } \\
(\%)\end{array}$ & $\begin{array}{c}\text { F.Sand } \\
(\%)\end{array}$ & $\begin{array}{l}\text { Silt } \\
(\%)\end{array}$ & $\begin{array}{c}\text { Clay } \\
(\%)\end{array}$ & & & & & \\
\hline $\mathbf{0 - 3 0}$ & 0.7 & 1.83 & 70.03 & 11.11 & 16.23 & 7.6 & 3.63 & 4.06 & 34.06 & 1.12 \\
\hline $30-60$ & - & - & - & - & - & 7.9 & 4.33 & 4.9 & - & 1.27 \\
\hline $60-90$ & - & - & - & - & - & 7.9 & 3.66 & 3.96 & - & 1.06 \\
\hline
\end{tabular}

Source: Omani Date Palm Project Team (2016).

\subsection{Climate Conditions at the Experimental Site}

The research field is situated in arid climatic region. The averages of air temperature, relative humidity, wind speed, sunshine duration and total precipitation were monitored by an in-situ meteorological station. The air water vapor pressure deficit was calculated using daily and hourly average temperatures and relative humidity. Finally, the reference evapotranspiration (ETo, mm day-1) was calculated according to the Penman-Montieth equation (Allen et al., 1998). Temperature is varying between 20.9 (minimum) and $34.8 \mathrm{C}$ (maximum). Humidity is about $59 \%$ and the wind speed is around $1.7 \mathrm{~ms}^{-1}$. Average estimated $\mathrm{ET}_{\mathrm{o}}$ is estimated to be $5.42 \mathrm{~mm} /$ day (Figure 1).

\subsection{Irrigation Systems Description and Experimental Interventions}

The study consists on the evaluation of four interventions as follows:

- INTERVENTION I: Irrigation with bubbler irrigation system at the rate of $100 \%$ of water requirements.

- INTERVENTION II: Irrigation with subsurface drip irrigation at the rate of $60 \%$ of water requirements.

- INTERVENTION III: Irrigation with subsurface drip irrigation at the rate of $40 \%$ of water requirements.

- INTERVENTION IV: Irrigation with subsurface drip irrigation at the rate of $20 \%$ of water requirements.

Water requirement was calculated based on the evapotranspiration coefficient and using the CROPWAT software. The $\mathrm{KC}$ coefficient used in the analysis has an average value of 0.9 for the date palm crop. 

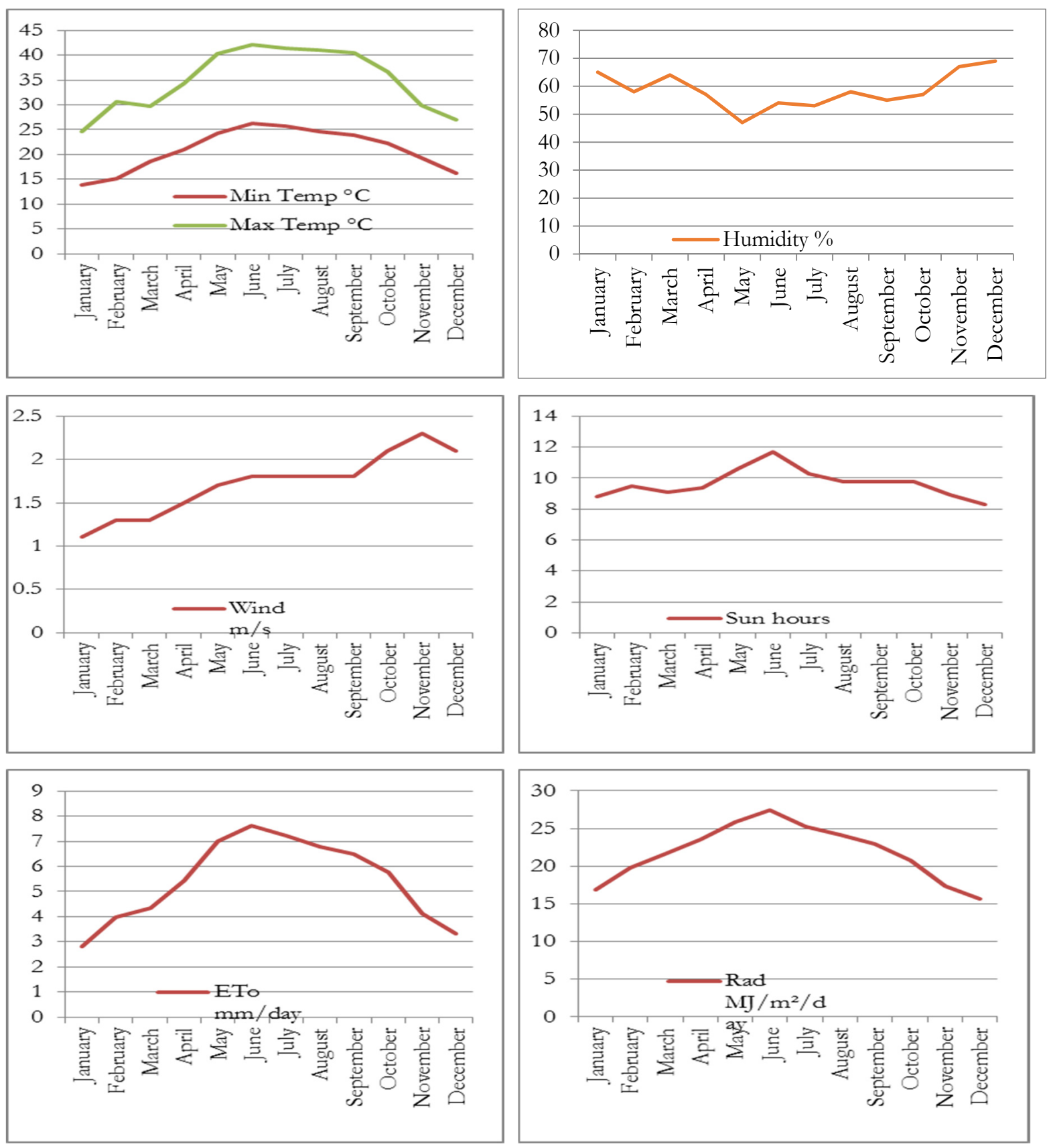

Figure 1 . The average monthly values of climatic conditions in the experimental site Source: Owen elaboration from experimental data (2017).

\subsection{Irrigation Scheduling and Experimental Test}

The monthly water irrigation schedule is presented in the table below (Table 2). Measurements covered the year 2015-2016. 
Table 2. Irrigation schedule and water applied to date palm variety Khalas in Al Kamil and Al Wafi experimental station at the Sharqyiah Governorate - Sultanate of Oman

\begin{tabular}{|c|c|c|c|c|c|c|}
\hline Month & $\begin{array}{c}\text { ETo } \\
\text { Weather station in } \\
\text { AL Kamil }(\mathrm{mm})\end{array}$ & $\begin{array}{c}\text { Ke } \\
\text { FAO }\end{array}$ & $\begin{array}{c}\text { Crop water } \\
\text { requirement }(\mathrm{mm} / \text { day })\end{array}$ & $\begin{array}{l}\text { Irrigated } \\
\text { Area }\left(\mathrm{m}^{2}\right)\end{array}$ & $\begin{array}{c}\text { Water } \\
\text { applied } \\
(\mathrm{mm} / \mathrm{month})\end{array}$ & $\begin{array}{c}\text { Total water } \\
\text { applied/month } \\
\left(\mathbf{m}^{3} / \text { month }\right)\end{array}$ \\
\hline January & 2.82 & 0.9 & 2.5 & 38 & 79 & 3.0 \\
\hline February & 3.97 & 0.9 & 3.6 & 38 & 100 & 3.8 \\
\hline March & 4.36 & 0.9 & 3.9 & 38 & 122 & 4.6 \\
\hline April & 5.45 & 0.9 & 4.9 & 38 & 147 & 5.6 \\
\hline May & 6.99 & 0.9 & 6.3 & 38 & 195 & 7.4 \\
\hline June & 7.64 & 0.9 & 6.9 & 38 & 206 & 7.8 \\
\hline July & 7.23 & 0.9 & 6.5 & 38 & 202 & 7.7 \\
\hline August & 6.93 & 0.9 & 6.2 & 38 & 193 & 7.3 \\
\hline September & 6.48 & 0.9 & 5.8 & 38 & 175 & 6.6 \\
\hline October & 5.76 & 0.9 & 5.2 & 38 & 161 & 6.1 \\
\hline November & 4.13 & 0.9 & 3.7 & 38 & 112 & 4.2 \\
\hline December & 3.32 & 0.9 & 3.0 & 38 & 93 & 3.5 \\
\hline \multicolumn{5}{|c|}{ Total } & 1783.7 & 67.8 \\
\hline
\end{tabular}

Source: Owen elaboration from experimental data -Date palm project team in Oman (2017).

The different measures and parameters used in the experience such as evapotranspiration, crop water requirement, water applied and total water applied are detailed in the figures below. Figures bellows (Figures 2-5) indicate that high values are noted during the summer season (May-August).

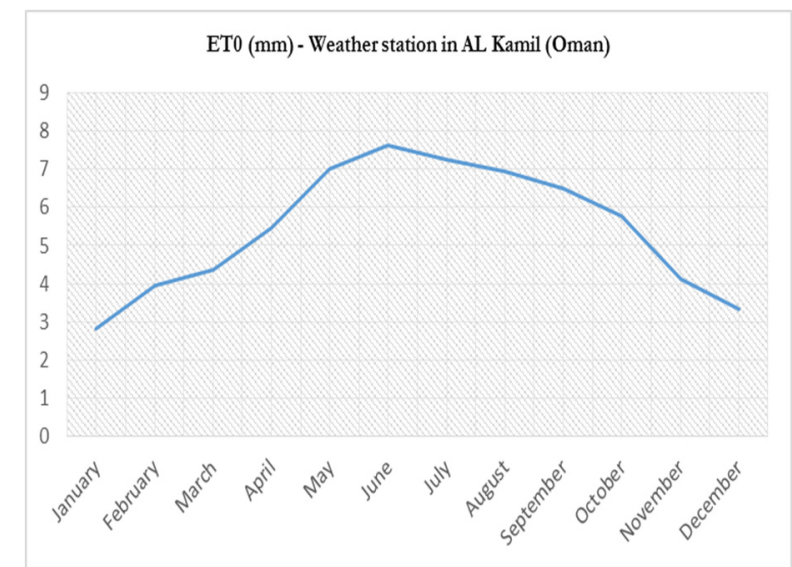

Figure 2. ET0 (mm) at the weather station in Al Kamil

Source: Owen elaboration from experimental data-Date palm project team in Oman (2017).

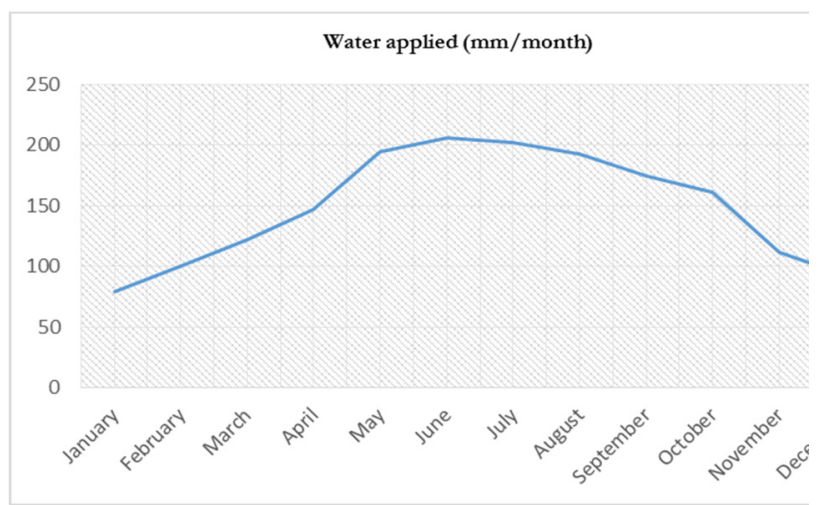

Figure 4. Water applied (mm/month)

Source: Owen elaboration from experimental data - Date palm project team in Oman (2017).

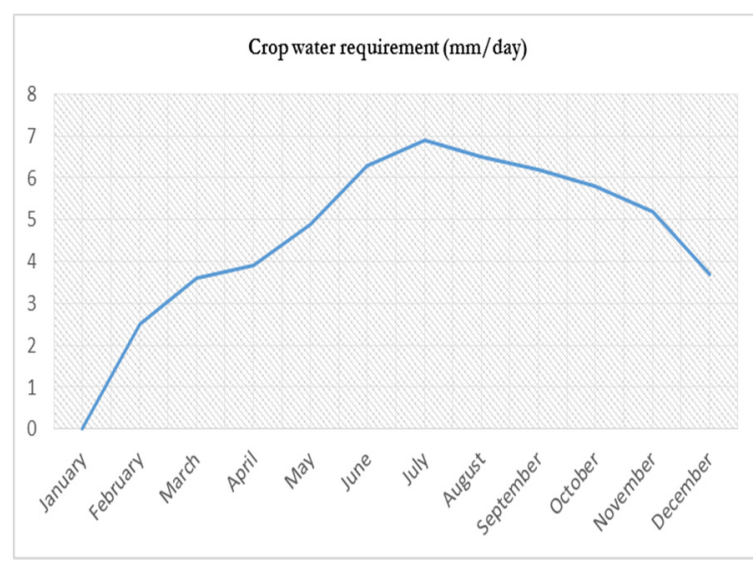

Figure 3. Crop water requirement ( $\mathrm{mm} /$ day)

Source: Owen elaboration from experimental data Date palm project team in Oman (2017).

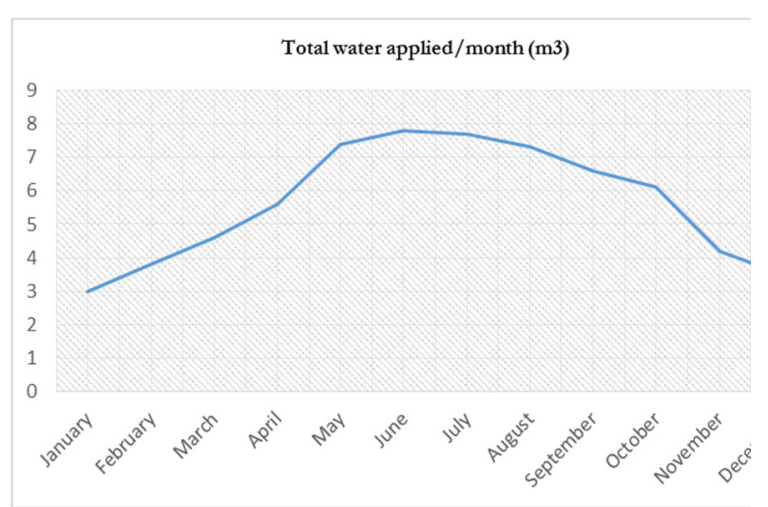

Figure 5. Total water applied/month $\left(\mathrm{m}^{3}\right)$

Source: Owen elaboration from experimental data Date palm project team in Oman (2017). 


\subsection{Experimental Irrigation Systems Description and Characteristics}

After several decades of research and development, the subsurface drip irrigation system becomes one of the systems characterized by high efficiency and productivity (Al Amoud, 2010). Through extensive research, most of the subsurface drip irrigation system problems were solved including; clogging of emitters by small roots, lateral installation, and fertigation. Findings of many research experiments have indicated a significant increase in efficiency of water and nitrogen use that lead to a high increase in yield, and, consequently improving the quality of date palm product. The system has also contributed in limiting ground water pollution with nitrate and salts in the long run. As the system work under the soil surface, it was noticed that it has an advantage over the traditional surface drip system in saving water and nutrients, in addition to the control of salinity, deep percolation and durability of the system. This may be due to the spherical soil water wetting as compared to the half spherical in the case of surface drip system (Phene, 1995).

Nowadays, different irrigation techniques are available to irrigate crops, including flood irrigation, furrow irrigation, micro irrigation, drip irrigation, and subsurface drip irrigation. However, but not all of them are suitable for date palm irrigation. The previous methods are of importance and each has its own advantages and disadvantages. In the following section, we present the advantages and limitations of the two irrigation methods considered for evaluation in the current study: Bubbler and subsurface drip irrigation.

Bubbler Irrigation System: Bubbler irrigation is a localized, low pressure, solid permanent installation system used in tree groves. Each tree has a round or square basin which is flooded with water during irrigation. The water infiltrates into the soil and wets the root zone. The water is applied through bubblers. These are small emitters placed in the basins which discharge water at flow rates of 100-250 litres $/ \mathrm{h}$. Each basin can have one or two bubblers as required. With bubbler irrigation the percentage of the root soil volume wetted is about 80 percent. Thus, there are no restrictions on the way the irrigation programme is prepared. This can be either fixed depletion or fixed interval, taking into consideration the soil water holding capacity, the availability of the irrigation water, the size of flow, etc. The advantages of this irrigation systems are as follows: (i) high irrigation application efficiency, up to 75 percent, resulting in considerable water savings, with absolute control of the irrigation water from the source to the tree basin; (ii) all the piping network is buried, so there are no field operations problems; (iii) the technology is simple and no highly sophisticated equipment is used; and finally (iv) the system can be operated by unskilled farmers and laborers. No filters or fertilizer injectors are needed. Therefore, this system presents some limitations such as: (i) high initial purchase cost; (ii) small water flows cannot be used as in other micro-irrigation systems; and (iii) in sandy soils with high infiltration rates, it is difficult to achieve a uniform water distribution over the tree basins.

Subsurface Drip Irrigation System: This technique has been defined as an application of water under the soil surface through drippers, which deliver water at rates generally similar to surface drip irrigation. As subsurface drip irrigation is a recently introduced in some Gulf countries, a better understanding of its performance in comparison with bubbler irrigation system (as the case in Oman), in local conditions, and its impact on water use and yield of date palm is necessarily required. Several research studies argued that SDI represents the recent improvement of irrigation and has the advantage to prevents, or in most cases, significantly reduces losses of direct evaporation, runoff and deep percolation. The precise application of water and fertilizers resulted in the increased water use efficiency, application uniformity of water and consequently the improvement in crop yield. Limitations of this technology are mainly resulted on its installation cost; requires very clean water; and sometimes difficult to determine if the correct amount of water has been applied by the system, and when it becomes clear that it is too little, it may be too late.

The main objective of this study is to examine the efficiency of subsurface drip irrigation system for Khalas palm trees in arid conditions, the experimental and demonstrative field is located in Al Kamil and Al Wafi Agricultural Research Station at South Sharqeyah Governorate (Figure $6 \&$ 7). The station is composed (among other) of a fully equipped weather station to measure rainfall, temperature, wind speed, wind direction, humidity and solar radiation. Our results will help to identify the most efficient technique for water conservation among BI and SDI, particularly for Khalas date palm variety in this arid farming systems.

\subsection{Factors Influencing Water Requirements}

For selecting the best field experiments, it is necessary to take certain aspects into consideration, particularly for the calculation of the volume of water required by a palm. The following aspects, playing a major role on influencing evapotranspiration, and consequently in this calculation, have been considered: 
- Soil salinity: If the soil is saline, more water must be given to enable a leaching process for clearing the salt from the soil.

- Temperature: The higher the temperature, the higher the rate of evaporation and the more water the plant needs.

- Humidity: The lower the humidity level, the more water needed.

- Wind (speed and occurrence): Higher constant wind speeds causes higher evaporation and thus higher water demands.

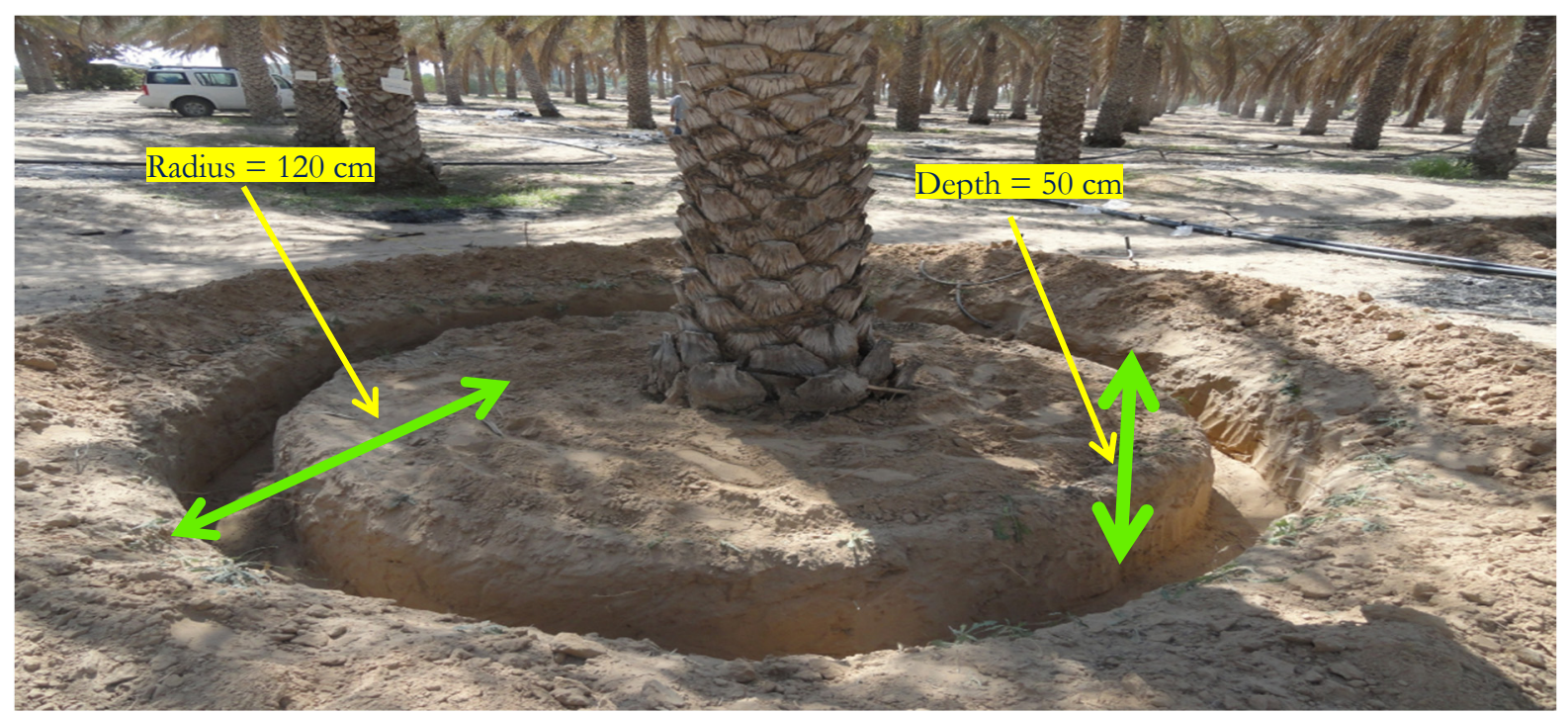

Figure 6. Installation of the subsurface drip irrigation system (Radius $120 \mathrm{~cm}$ and Depth $50 \mathrm{~cm}$ )

Source: Owen elaboration from experimental data -Date palm project team in Oman (2017).
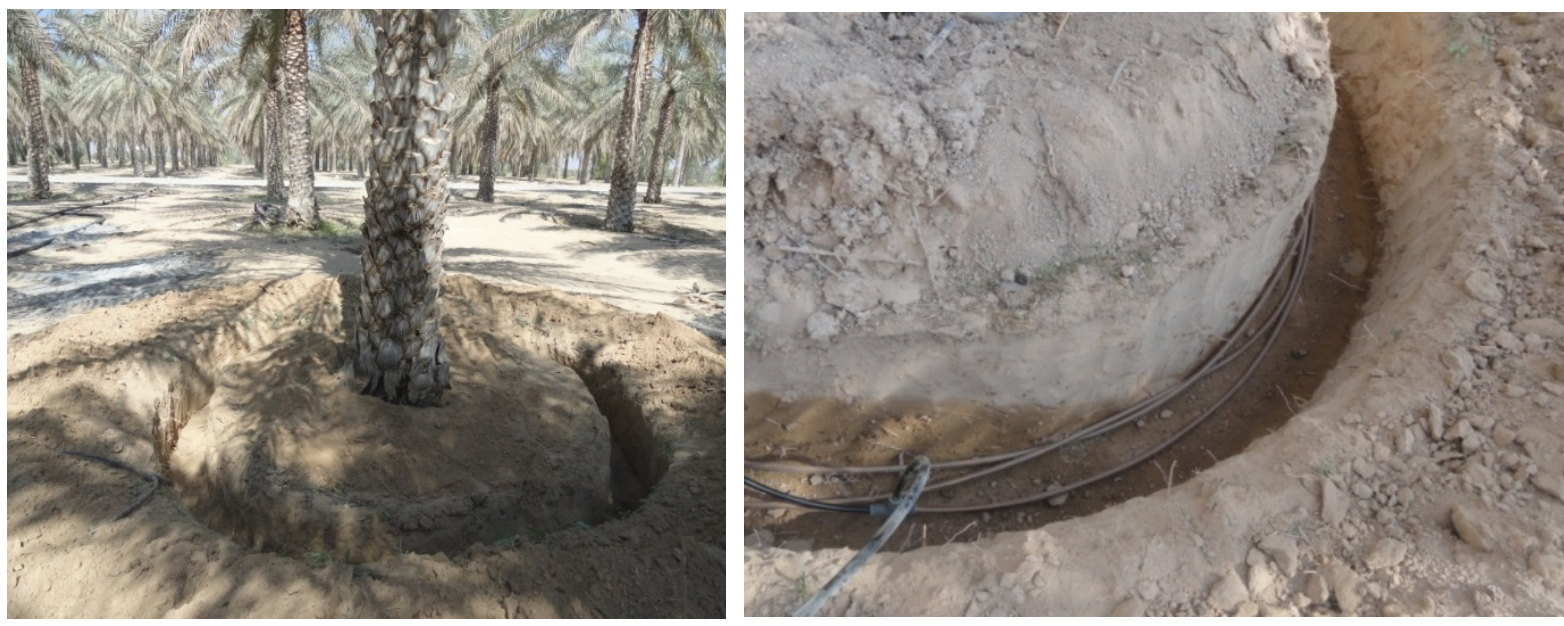

Figure 7. Subsurface drip irrigation system

Source: Owen elaboration from experimental data -Date palm project team in Oman (2017). 


\subsection{Data Collection and Methodological Framework}

\subsubsection{Data Collection}

As mentioned before, data on water applied, required, temperature, evapotranspiration has been collected from the experimental study conducted at Al Kamil and Al Wafi Agricultural Research Station at South Sharqeyah Governorate, Oman. The socio economics data used was collected from several national and international sources.

\subsubsection{Water Use Efficiency (WUE)}

Water use efficiency - WUE was calculated as a ratio between the marketable yield and the seasonal values of actual evapotranspiration using the following equation (Howell, 2001):

$$
\mathrm{WUE}=\mathrm{Y} / \mathrm{W}
$$

Where WUE is water use efficiency $\left(\mathrm{kg} / \mathrm{m}^{3}\right), \mathrm{Y}$ is total marketable date palm yield $(\mathrm{kg})$ and $\mathrm{w}$ is seasonal irrigation applied water $\left(\mathrm{m}^{3}\right)$.

\subsubsection{Economic Analysis}

Partial budgeting method is used for economic comparison between both irrigation systems (BI vs SDI).

\subsubsection{Statistical Analysis}

Data collected was examined statistically by using the ANOVA procedure from the statistical analysis software (SPSS). To compare treatment means, Fisher's protected least significant difference (LSD) was used for ( $\mathrm{p} \leq 0.05)$ significant level.

\section{Results and Discussion}

\subsection{Economic Evaluation: Date Palm Yield (DPY)}

The effect of the irrigation interventions on the date palm productivity is presented in the table and figures below (Table 3 \& Figures 8, 9). The empirical figures displayed in the table below indicate that no significant difference on the date palm productivity under the intervention I, irrigation with bubbler irrigation system at the rate of $100 \%$ of water requirements and the intervention II (irrigation with subsurface drip irrigation at the rate of $60 \%$ of water requirements).

Table 3. Date palm productivity under the four irrigation interventions level $(\mathrm{Kg} /$ tree and $\mathrm{Kg} / \mathrm{ha})$

\begin{tabular}{lcc}
\hline Irrigation intervention type & $\begin{array}{c}\text { Yield - Experimental } \\
\text { Irrigated Area } \\
\text { (Kg/tree) }\end{array}$ & $\begin{array}{c}\text { Yield - Potential } \\
\text { Irrigated Area } \\
\text { (Kg/ha) }\end{array}$ \\
\hline $\begin{array}{l}\text { INTER I: Irrigation with bubbler irrigation system (BI) at the rate of } \\
100 \% \text { of water requirements }\end{array}$ & 79.0 & 12956 \\
INTER II: Irrigation with subsurface drip irrigation (SDI) at the rate of & 78.3 & 12841.2 \\
60\% of water requirements & 69.8 & 11447.2 \\
INTER III: Irrigation with subsurface drip irrigation (SDI) at the rate of & 68.8 & 11283.2 \\
\hline $\begin{array}{l}\text { INTE of water requirements } \\
\text { 20\% of water requirements }\end{array}$ & \\
\hline
\end{tabular}

Source: Owen elaboration from experimental data -Date palm project team in Oman (2017).

Note: Number of date palm trees/ha $\left(10000 \mathrm{~m}^{2}\right)=164$.

The productivity level under the first irrigation system is about $79 \mathrm{~kg} /$ tree, while it was around $78.3 \mathrm{~kg} /$ tree under the second system. However, under the third (irrigation with subsurface drip irrigation at the rate of $40 \%$ of water requirements) and fourth intervention (irrigation with subsurface drip irrigation at the rate of $20 \%$ of water requirements), the productivity of the date palm - variety Khalas decreased to reach an average of $69.8 \mathrm{~kg} / \mathrm{tree}$ and $68.8 \mathrm{~kg} /$ tree, respectively (Figure $8 \&$ Figure 9). 


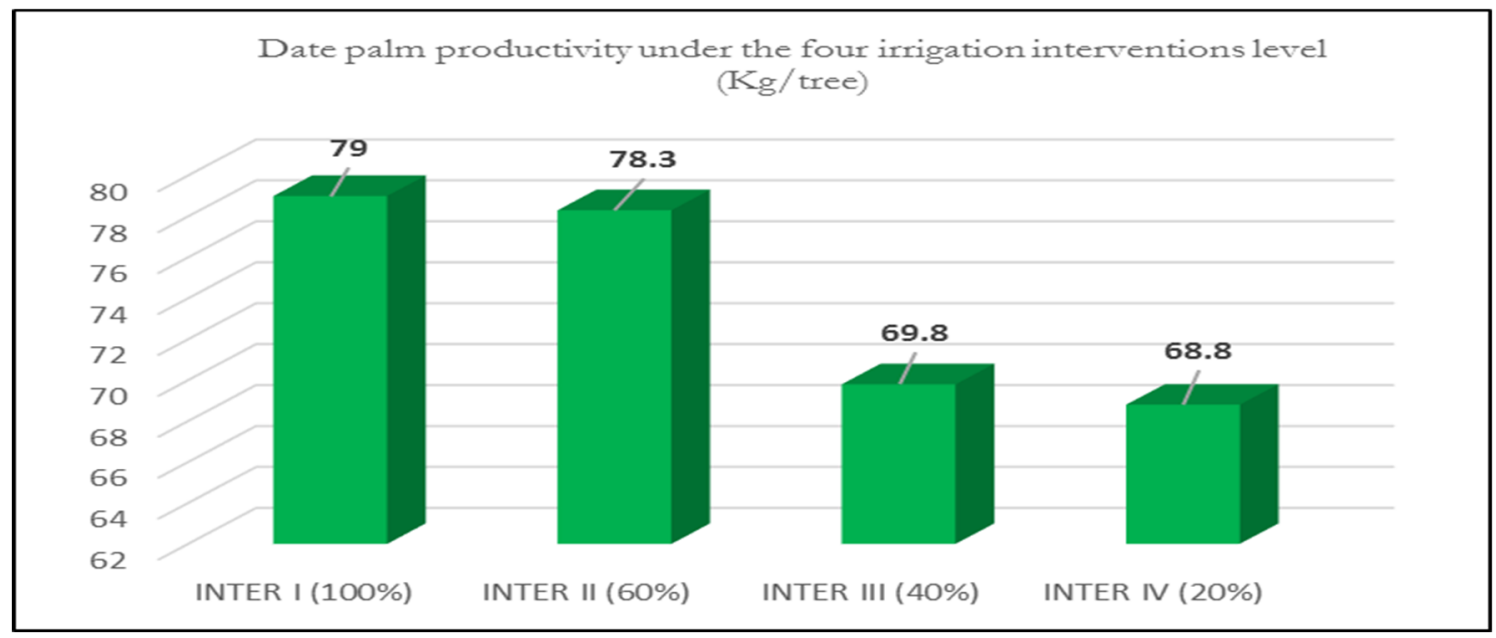

Figure 8. Date palm productivity under the four irrigation interventions level ( $\mathrm{Kg} / \mathrm{tree})$

Source: Owen elaboration from experimental data -Date palm project team in Oman (2017).

Statistical analysis showed that no significant difference of productivity was recorded between the first and second interventions. The same result was also found for the third and fourth interventions at the 0.05 statistical level. In general, the difference on productivity between Inter I, Inter II, Inter III, and Inter IV is, on average, for about 0.7 $\mathrm{kg} /$ tree, $9.2 \mathrm{~kg} /$ tree, and $10.2 \mathrm{~kg} /$ tree, respectively. This difference is about $114.8,1508.8$, and $1672.8 \mathrm{~kg}$ per hectare, respectively.

At the current market price $(0.8 \mathrm{OMR} / \mathrm{kg}$ the Khalas variety), we note a difference of about US\$238.78, US\$3138.30, and US\$3479.42 at the hectare, between the BI and the three SDI interventions, respectively. However, if we want to evaluate the real return and the net profit, we must consider the cost of water for each intervention in addition to the running costs in each case.

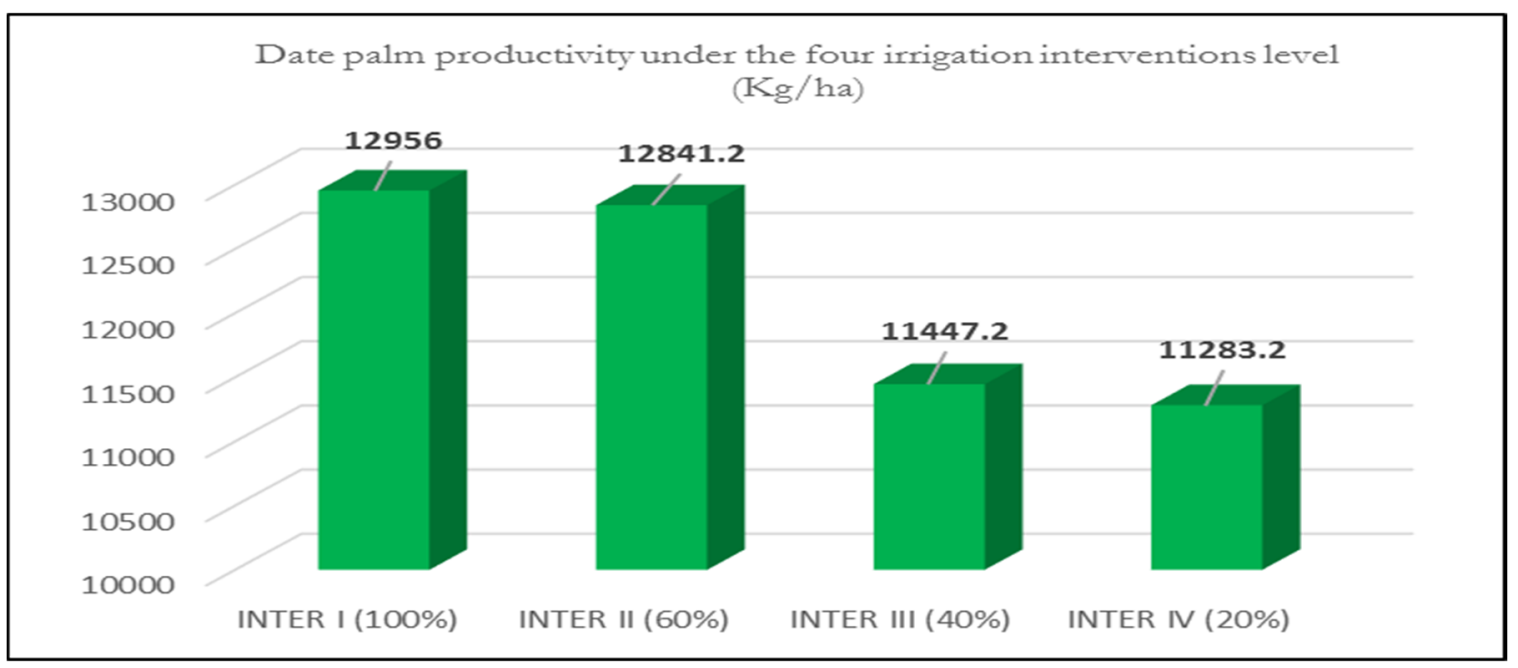

Figure 9. Date palm productivity under the four irrigation interventions level $(\mathrm{Kg} / \mathrm{ha})$

Source: Owen elaboration from experimental data -Date palm project team in Oman (2017).

\subsection{Technical Evaluation: Water Use Efficiency (WUE)}

This section presents an assessment if the water use efficiency of both SDI and BI irrigation methods. Empirical findings are presented in the following figures (Figure 10). 


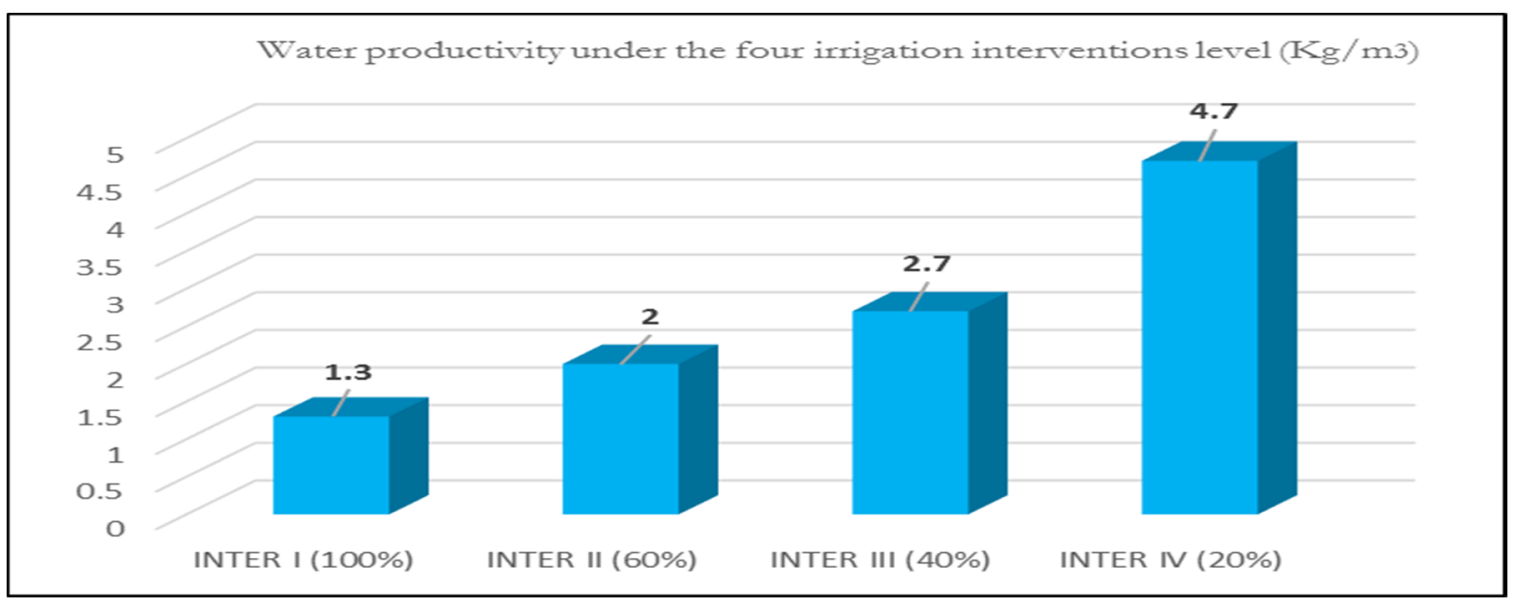

Figure 10. Water productivity under the four SDI irrigation interventions $\left(\mathrm{Kg} / \mathrm{m}^{3}\right)$

Source: Owen elaboration from experimental data -Date palm project team in Oman (2017).

Results shows that water productivity $(\mathrm{kg} / \mathrm{m} 3)$ increase with the decrease of water quantity. Findings indicated that the fourth intervention (irrigation with subsurface drip irrigation at the rate of $20 \%$ of water requirements) is the most efficient. Data shown in figures9-10 demonstrates that WUE was significantly increased by 35, 52, and $72 \%$ in case of subsurface drip irrigation (SDI) under the three intervention levels $\left(60 \%\right.$ with WUE $=2 \mathrm{~kg} \mathrm{~m}^{-3}$, $40 \%$ with WUE $=2.7 \mathrm{~kg} \mathrm{~m}^{-3}$, and $20 \%$ with $\mathrm{WUE}=4.7 \mathrm{~kg} \mathrm{~m}^{-3}$ ) compared to bubbler irrigation (BI with WUE $=1.3$ $\mathrm{kg} \mathrm{m}^{-3}$ ). These findings confirmed that SDI contribute to save 35 and $72 \%$ (depending on the implemented intervention) of irrigation water without decreasing the Khalas date palm productivity level.

These results suggest that, from the Technical point of view, a significant reduction in the volume of water can be achieved when using SDI system. This amount of water saved by hectare under the three SDI options $60 \%, 40 \%$, and $20 \%$ is estimated to be $3545.554,5726.45$, and $7565.473 \mathrm{~m}^{3}$, respectively. At an estimated average price of US\$0.041 per $\mathrm{m}^{3}$ of irrigation water, the average dollar value saved by hectare under the three options will be around US\$ 145.36; US\$ 234.78; and US\$ 310.18, respectively.

Table 4. Quantity of water consumed and saved under the four irrigation interventions level (m3/ha and US\$/ha) - SI vs SDI

\begin{tabular}{|c|c|c|c|c|c|c|c|}
\hline $\begin{array}{l}\text { Irrigation } \\
\text { intervention }\end{array}$ & $\begin{array}{c}\text { Water Use } \\
\text { Efficiency } \\
(\mathrm{kg} / \mathrm{m3})\end{array}$ & $\begin{array}{c}\text { Total Water } \\
\text { Consumed } \\
\left(\mathbf{m}^{3} / \mathbf{h a}\right)\end{array}$ & $\begin{array}{c}\text { Total } \\
\text { Water } \\
\text { Saved } \\
\left(\mathbf{m}^{3} / \mathbf{h a}\right) \\
\text { BI vs SDI }\end{array}$ & $\begin{array}{c}\text { Potential } \\
\text { Water Saving } \\
\text { (US\$/ha) } \\
\text { BI vs SDI } \\
\text { Scenario I } \\
\end{array}$ & $\begin{array}{c}\text { Potential } \\
\text { Water Saving } \\
\text { (US\$/ha) } \\
\text { BI } s \text { SDI } \\
\text { Scenario II } \\
\end{array}$ & $\begin{array}{c}\text { Potential } \\
\text { Water Saving } \\
\text { (US\$/ha) } \\
\text { BI vs SDI } \\
\text { Scenario III } \\
\end{array}$ & $\begin{array}{c}\text { Potential } \\
\text { Water Saving } \\
\text { (US\$/ha) } \\
\text { BI } s \text { SDI } \\
\text { Scenario IV }\end{array}$ \\
\hline INTER I & 1.3 & 9966.154 & - & - & - & - & - \\
\hline INTER II & 2.0 & 6420.6 & 3545.554 & 74.456634 & 109.912174 & 145.367714 & 180.823254 \\
\hline INTER III & 2.7 & 4239.704 & 5726.45 & 120.25545 & 177.51995 & 234.78445 & 292.04895 \\
\hline INTER IV & 4.7 & 2400.681 & 7565.473 & 158.874933 & 234.529663 & 310.184393 & 385.839123 \\
\hline
\end{tabular}

Source: Owen elaboration from experimental data -Date palm project team in Oman (2017).

Note:

- Number of date palm trees/feddan $\left(4200 \mathrm{~m}^{2}\right)=64$.

- $\quad$ Number of date palm trees/ha $\left(10000 \mathrm{~m}^{2}\right)=164$.

- Water pricing scenarios: The combined capital, maintenance and energy cost of pumping groundwater from a typical dug well for traditional irrigation is estimated at about US $\$ 0.021 / \mathrm{m}^{3}$ (Scenario I) and US\$0.031/ $\mathrm{m}^{3}$ (Scenario II) for average conditions). Pumping costs from a tube well for a modem irrigation system, requiring a larger pumping head, are between US\$0.041 (Scenario III) and 0.051/ $\mathrm{m}^{3}$ (Scenario IV).

The results presented in the table above (Table 4) indicated that there is a potential cost saving by using subsurface drip irrigation (under the tree intervention types) in comparison to bubbler irrigation system (BI). This saving is ranging from $74.45 \$$ ha to $385.8 \$ /$ ha according to the SDI irrigation intervention category used. This result 
suggests that a considerable amount of water (in terms of quantity and value) could be potentially saved by using SDI, and consequently a more sustainable farming system for Khalas date palm variety in the research site, in particular and, in the Sultanate of Oman, in general.

\subsection{Economic Analysis (EA)}

Total annual date palm water use will certainly have a significant impact on the water costs. Thus, the irrigation method will clearly affect the total return and the net profit. In addition, we should indicate that initial cost (equipment and installation) for SDI system is higher than the BI system.

Hypotheses used in this economic analysis are as follows:

- $\quad$ The expected life of the bubble irrigation system (BI) is 10 years.

- The expected life of the subsurface drip irrigation system (SDI) is 10 years

- The economic analysis was conducted taking into consideration the depreciation of the installed irrigation system in both cases. Results are at the hectare level and per year.

- The price of one $\mathrm{m}^{3}$ of irrigated water used in the analysis is US\$0.041.

- $\quad$ One Omani Rial (OMR) = 2.60 \$ (average January-March 2017).

- The average cost of installing bubbler irrigation system (equipment and installation) at the hectare is estimated at 1963 OMR (which is equivalent to US\$5098.04) ha. The cost of operation and maintenance is estimated at $6 \%$ of the equipment and installation cost per ha and year: US\$305.88.

- The quantity of water used for one ha of Khalas date palm trees using bubbler irrigation system is estimated at $9966.154 \mathrm{~m}^{3}$. The cost of this water used is around US\$408.61.

- The average cost of installing subsurface drip irrigation (equipment and installation) is estimated at 2614 OR (equivalent to US\$ 6788.73). The cost of operation and maintenance is estimated at $6 \%$ of the equipment and installation cost per ha and year: US\$ 407.32.

- The quantity of water used for one ha of Khalas date palm trees using subsurface drip irrigation system at the level of 60,40 , and $20 \%$ of water requirement is estimated at $6420.6,4239.704$, and $2400.68 \mathrm{~m}^{3}$, respectively. The cost of the used amount of water is US\$145.36, US\$234.78, and US\$310.18, respectively.

The empirical findings are presented in Table 5. Results displayed in this table shows the effect of irrigation method on water cost, total return and net profit considered in average values at the hectare level. The results indicated that, under bubbler (BI) irrigation system, the total return, total variable costs, water costs and net profit were 20211.36, 5857.81, 1224.29, and 13129.25 \$ ha $\mathrm{h}^{-1}$, respectively. In addition, we noted a slight difference in net profit when using SDI at the rate of $60 \%$ of water requirements. This additional benefit will be about US\$12825.02/ha.

Table 5. Effect of irrigation method on total cost, total return and net profit - Variety Khalas

\begin{tabular}{|c|c|c|c|c|c|}
\hline Irrigation intervention & $\begin{array}{l}\text { Yield - Potential } \\
\text { Irrigated Area } \\
\text { (Kg/ha) }\end{array}$ & $\begin{array}{c}\text { Total } \\
\text { Return } \\
\text { (\$/ha) }\end{array}$ & $\begin{array}{c}\text { Total } \\
\text { Variable } \\
\text { Costs } \\
\text { (\$/ha) }\end{array}$ & $\begin{array}{l}\text { Water } \\
\text { Costs } \\
(\$ / \text { ha) }\end{array}$ & $\begin{array}{c}\text { Net } \\
\text { Profit } \\
\text { (\$/ha) }\end{array}$ \\
\hline $\begin{array}{l}\text { INTER I: Irrigation with bubbler }(\mathbf{B I}) \text { at the rate of } \\
100 \% \text { of water requirements }\end{array}$ & 12956 & 20211.36 & 5857.81 & 1224.29 & 13129.25 \\
\hline $\begin{array}{l}\text { INTER II: Irrigation with subsurface drip irrigation } \\
\text { (SDI) at the rate of } 60 \% \text { of water requirements }\end{array}$ & 12841.2 & 20032.27 & 5857.81 & 1349.43 & 12825.02 \\
\hline $\begin{array}{l}\text { INTER III: Irrigation with subsurface drip } \\
\text { irrigation (SDI) at the rate of } 40 \% \text { of water } \\
\text { requirements }\end{array}$ & 11447.2 & 17857.63 & 5857.81 & 1260.02 & 10739.80 \\
\hline $\begin{array}{l}\text { INTER IV: Irrigation with subsurface drip } \\
\text { irrigation (SDI) at the rate of } 20 \% \text { of water } \\
\text { requirements }\end{array}$ & 11283.2 & 17601.79 & 5857.81 & 1184.62 & 10559.36 \\
\hline
\end{tabular}

Source: Owen elaboration from experimental data -Date palm project team in Oman (2017).

Notes: 
- $\quad$ Number of date palm trees/feddan $\left(4200 \mathrm{~m}^{2}\right)=64$.

- Number of date palm trees/ha $\left(10000 \mathrm{~m}^{2}\right)=164$.

- The market price of the variety Khalas is estimated to be 0.8 OMR (2.08\$).

- The total variable costs were estimated at US\$5202.57/ha (Dhehibi et al., 2016).

- In the total return, we consider only $75 \%$ of the production is marketable ( $25 \%$ are considered as waste).

- Water costs are calculated using the following estimations: For both irrigation systems (BI and SDI), the irrigation/water cost by hectare includes the equipment cost (depreciation), operating, maintenance cost, and the value of the consumed amount of water.

Furthermore, by using SDI at the rate of 40 and $20 \%$, we note a significant difference in net profit compared to the benefit recorded when using bubbler irrigation method. This difference is ranging between 2389.45 \$ha $^{-1}$ (SDI at $40 \%$ of water requirement) and $2569.89 \$ \mathrm{Sh}^{-1}$ (SDI at $20 \%$ of water requirement). This analysis showed that total return and net profit values of Khalas date palm trees increased with the BI irrigation method in comparison to the SDI (under the three interventions). This fact is due to two major factors: The first one is the amount of water used by BI which impact the yield and consequently the total return. The second factor is the increase in water costs generated mainly by the high upfront investment cost (Both equipment and installation) of SDI in comparison with $\mathrm{BI}$ investment cost.

The capital cost associated with installing such a system limits the feasibility of adopting this technology at the short time. Therefore, in the medium and long run periods, the sensitivity of investment and water saving indicate that installation of SDI for date palm trees production system and its use under the three interventions could be profitable investment. Thus, using SDI at the $60 \%$ rate of water requirement, if combination equivalent to 12841.2 $\mathrm{kg} / \mathrm{ha} /$ year, valued at $\$ 20032.27 / \mathrm{ha} /$ year, coupled with $35 \%$ water savings, valued, on average and per year and hectare, at $74.45 \$$. In a period of ten (10) years, the total value of net profit is estimated to be US\$3040/ha. Therefore, the water saving will be around $744.5 \$$ ha. This result suggest the existence of water economic profitability in the long term by using SDI system in the date palm farming.

\section{Concluding Remarks and Policy Implications}

The aim of the first section of this report was to examine the performance of bubbler irrigation system (BI) and subsurface drip irrigation systems (SDI) at Al Kamil and Al Wafi Agricultural Research Station - South Sharqiya, Sultanate of Oman. The performance of both systems was evaluated in terms of water use efficiency, economic performance, and yield of date palms (Cv. Khalas). Three intervention levels on SDI have been used: subsurface drip irrigation at the rate of $60 \%$ of water requirement, SDI at the rate of $40 \%$ of water requirement, and SDI at the rate of $20 \%$ of water requirement. Results of this experimental study showed that SDI under the three intervention/options uses water more efficient in comparison to the BI system. Indeed, a considerable quantity of water for about $3545.554,5726.45$, and $7565.473 \mathrm{~m}^{3} / \mathrm{ha}$ could be saved by using SDI at the rate of $20 \%, 40$ and $60 \%$ of water requirements, respectively. Thus, the WUE indicator is for about $2.0,2.7$ and $4.7 \mathrm{~kg} / \mathrm{m}^{3}$, respectively. These figures are much higher when are compared to BI system where WUE is around $1.3 \mathrm{kgm}^{-3}$.

The economic evaluation and comparison between both systems suggest a considerable effect of the used irrigation method on the water cost, total return and net profit. Indeed, under BI irrigation system, the total return, total variable costs, water costs and net profit were 20211.36, 5857.81, 1224.29, and 13129.25 $\$$ ha $^{-1}$, respectively. From another hand, by using SDI at the rate of $60 \%$ of water requirements, we note a slight difference in net profit when using this irrigation system, which is about US\$12825.02/ha. Economic findings suggest that using SDI method versus BI method have additional cost but is economical at the long term as the SDI found to sustain the date palm farming system in this region where arid conditions acts as natural constraints for expansive agriculture. Therefore, this sustainability of SDI in comparison to the BI could be reached if SDI system is well designed, maintained and used properly.

Furthermore, based on the results of this experiment, (although measured for only one season), it is possible to conclude that subsurface drip irrigation for date palms is an effective and practical method for irrigating date palms where, a noticeable volume of water could be saved due to the elimination of evaporation water compared to other irrigation systems including the BI system. In addition, under the arid and semiarid climates conditions, as the focused studied region, where rainfall is minimal and the air temperature is high, this will result in high increase in evaporation rate from soil surface that result in salt accumulation in the top layer of the soil where active roots 
concentrates which in turn lead to yield reduction, the use of SDI system could eliminate the weed growth around the tree and prevent salt accumulation on the soil surface.

\section{Recommendations}

Results from the present research study in Oman suggest the following:

- It is understood from the study that investment/capital cost required to install subsurface drip irrigation is relatively high. Therefore, measures can preliminary be taken to reduce the cost of equipment by promoting production and supply of low cost SDI systems.

- The adoption of modern irrigation techniques such as drip and subsurface drip irrigation is more than needed today for these very arid regions. This is mainly to increase water use efficiency and date palm productivity. Therefore, in the short time, the capital cost associated with installing such a system limits the probability of adopting this technology. This suggests that:

- Research on SDI should be given the required attention in order to be able to produce low cost SDI systems.

- Training programs should be conducted for farmers on the design, maintenance and the proper use of these SDI systems.

- Extension education programs are to be developed, improved and implemented, through community involvement, in order to enhance farmers' adoption rates of modern irrigation methods.

- To accelerate the adoption process of these technologies, it is imperative to create favourable conditions so that a greater number of farmers can take advantage from the benefits of such technologies. A creation of a strong networking among different institutions related to applying this modern irrigation technology and involvement of public and private financial institutions and support services could be an example of mechanisms to enhance adoption.

- Further studies could be carried out to investigate the barriers of adoption of new irrigation method by farmers and develop solutions to overcome these barriers to conserve limited water resources for obtaining Omani sustainable agriculture goals.

\section{Acknowledgment}

We would like to express our sincere gratitude and appreciation to the Gulf Cooperation Council (GCC) Secretariat for funding this research conducted in the framework of the "Development of sustainable date palm production systems in the GCC countries of the Arabian Peninsula" project. We are very grateful to the Ministries of Agriculture, Agricultural Authorities, and Agricultural Research Institutions and Universities in the GCC countries of the Arabian Peninsula for their continuous support and great collaboration in the implementation of the project activities.

\section{References}

Al-Amoud, A. I. (2010, March). Subsurface drip irrigation for date palm trees to conserve water. In $I V$ International Date Palm Conference 882 (pp. 103-114). Retrieved from http://www.actahort.org/books/ 882/882_11.htm

Al-Amoud, A. I., Bacha, M. A., \& Al-Darby, A. M. (2000). Seasonal water use of date palms in the central region of Saudi Arabia. International Agricultural Engineering Journal, 9(2), 51-62.

Allen, R. G., Pereira, L. S., Raes, D., \& Smith, M. (1998). Crop evapotranspiration-Guidelines for computing crop water requirements-FAO Irrigation and drainage paper 56. Fao, Rome, 300(9), D05109. Retrieved from https://appgeodb.nancy.inra.fr/biljou/pdf/Allen_FAO1998.pdf

Al-Yahyai, R., \& Al-Kharusi, L. (2012). Sub-optimal irrigation affects chemical quality attributes of dates during fruit development. African Journal of Agricultural Research, 7(10), 1498-1503. https://doi.org/10.5897/ AJAR11.1553

Al-Yahyai, R., \& Khan, M. M. (2015). Date palm and perspective in Oman. In J. M. Al-Khayri, S. M. Jain, \& D. V. Johnson (Eds.), Date Palm Genetic Resources and Utilization Volume 2: Asia and Europe (pp. 207-240). New York, London: Springer, Dordrecht, Heidelberg.

ASAE Std.. (1999). Soil and Water Terminology. S 526.1. ASAE Standards. American Society of Agricultural Engineers, St. Joseph M.I. Retrieved from https://american-jiras.com/Ahmed\%20ManuscriptRef.2ajiras010716\%20SAUDI2.pdf 
Ayers, J. E., Phene, C. J., Schoneman, R. A., Meso, B., Dale, F., \& Penland, J. (1995). Impact of bed location on the operation of subsurface drip irrigation systems. In Proc. $5^{\text {th }}$ int Microirrigation Congress, ASAE (pp. 168-174).

Bourziza, R., Hammani, A., Kuper, M., \& Bouaziz, A. (2014). Water Saving in Arid Regions: Comparison of Innovative Techniques for Irrigation of Young Date Palms. World Academy of Science, Engineering and Technology. International Journal of Environmental, Chemical, Ecological, Geological and Geophysical Engineering, 8(11), 2014. Retrieved from http://citeseerx.ist.psu.edu/viewdoc/download?doi=10.1.1. 665.2130\&rep $=$ rep1\&type $=$ pdf

Dewidar, A. Z., Al-Fehaid, Y., Al-Hilal, S., \& Ben Saleh, M. (2016). Water saving in arid regions. A comparison of surface and subsurface drip irrigation systems. American Journal of Innovative Research and Applied Sciences.

Dhehibi, B. (2017). Economic comparison and evaluation of manual and liquid pollination methods of date palm trees in the Sultanate of Oman (varieties Fardh and Khalas).

Douh, B., \& Boujelben, A. (2010). Water saving and eggplant response to subsurface drip irrigation. Journal of Agricultural Segment, 1(2), 1525.

El Mardi, M. O., Salama, S. B., Consolacion, E. C., \& Al-Solomi, M. (1998). Effect of treated sewage water on the concentration of certain nutrient elements in date palm leaves and fruits. Communications in soil science and plant analysis, 29(5-6), 763-776. http://dx.doi.org/10.1080/00103629809369983

El Mardi, M. O., Salama, S. B., Consolacion, E., \& Al - Shabibi, M. S. (1995). Effect of treated sewage water on vegetative and reproductive growth of date palm. Communications in soil science and plant analysis, 26(1112), 1895-1904. http://dx.doi.org/10.1080/00103629509369416

Hanson, B., \& May, D. (2007). The effect of drip line placement on yield and quality of drip-irrigated processing tomatoes. Irrigation and drainage systems, 21(2), 109-118.

Howell, T. A. (2001). Enhancing water use efficiency in irrigated agriculture. Agronomy Journal, 93(2), $281-289$.

Payero, J. (2002). Is subsurface drip irrigation right for your operations?. Crop watch new service web page, Univ. of Nebraska, Institute of Agriculture and Natural Resources Cooperative Extension.

Phene C. J. (1995). Sustainability and potential of subsurface drip irrigation. In Proceedings of the Fifth International Micro Irrigation Congress, Orlando, Florida (pp. 359-367).

Safi, B., Neyshabouri, M. R., Nazemi, A. H., Massiha, S., \& Mirlatifi, S. M. (2007). Water application uniformity of a subsurface drip irrigation system at various operating pressures and tape lengths. Turkish Journal of Agriculture and Forestry, 31(5), 275-285.

Selim, E. M., Mosa, A. A., \& El-Ghamry, A. M. (2009). Evaluation of humic substances fertigation through surface and subsurface drip irrigation systems on potato grown under Egyptian sandy soil conditions. Agricultural water management, 96(8), 1218-1222.

Singh, D. K., \& Rajput, T. B. S. (2012). Response of lateral placement depths of subsurface drip irrigation on okra (Abelmoschus esculentus). International Journal of Plant Production, 1(1), 73-84. https://doi.org/10.22069/ IJPP.2012.527

Thompson, T. L., Doerge, T. A., \& Godin, R. E. (2002). Subsurface drip irrigation and fertigation of broccoli: II. Agronomic, economic, and environmental outcomes. Soil Science Society of America Journal, 66(1), 178185.

Thompson, T. L., White, S. A., Walworth, J., \& Sower, G. J. (2003). Fertigation frequency for subsurface dripirrigated broccoli. Soil science Society of America journal, 67(3), 910-918. http://doi.org/10.2136/sssaj2003. 9100

Tiwari, K. N., Mal, P. K., Singh, R. M., \& Chattopadhyay, A. (1998). Response of okra (Abelmoschus esculentus (L.) Moench.) to drip irrigation under mulch and non-mulch conditions. Agricultural water management, 38(2), 91-102. http://doi.org/10.1016/S0378-3774(98)00063-8

\section{Copyrights}

Copyright for this article is retained by the author(s), with first publication rights granted to the journal.

This is an open-access article distributed under the terms and conditions of the Creative Commons Attribution license (http://creativecommons.org/licenses/by/4.0/). 